ISSN (Print) : 1412-7601

ISSN (Online) : 2654-8712

Volume 7, No.2 September 2021

EKONOBIS

http://www.ekonobis.unram.ac.id

\title{
Dampak Pandemi Covid-19 Pada Pengusaha Kerupuk Kulit di Desa Apitaik Kabupaten Lombok Timur
}

\section{Adhitya Bagus Singandaru.}

Universitas Mataram

\begin{tabular}{|c|c|}
\hline ARTICLE INFO & \\
\hline $\begin{array}{l}\text { Keywords: } \\
\text { Covid-19 Pandemic, } \\
\text { Economic Impact, UMKM }\end{array}$ & $\begin{array}{l}\text { ABSTRACT : The Covid-19 pandemic is still a scourge to this day. In addition to having } \\
\text { an impact on health, this pandemic has also greatly impacted the national economy. } \\
\text { UMKM, which was considered capable of surviving the } 1998 \text { Monetary Crisis and the } \\
2008 \text { Global Crisis, is now powerless in the face of the COVID-19 pandemic. } \\
\text { The impact of the Covid-19 pandemic is not only felt by UMKM in big cities, UMKM } \\
\text { that is far from the city also feel the same impact, as felt by 'kerupuk kulit' } \\
\text { entrepreneurs in Apitaik Village, East Lombok Regency. } \\
\text { The results of interviews with several informants showed that the demand for } \\
\text { 'kerupuk kulit' during the pandemic increased, but producers did not dare to increase } \\
\text { prices because they were worried that their products would not be absorbed in the } \\
\text { market. In addition, the large number of sellers who sell at low prices makes 'kerupuk } \\
\text { kulit' entrepreneurs still use pre-pandemic prices. } \\
\text { 'Kerupuk kulit' entrepreneurs choose to cut their margins due to rising raw material } \\
\text { prices and shipping rates rather than increasing selling prices. As a result, many } \\
\text { 'kerupuk kulit' entrepreneurs have had to lower their employees' wages or even lay } \\
\text { off their employees. }\end{array}$ \\
\hline $\begin{array}{l}\text { Kata Kunci: } \\
\text { Pandemi Covid-19, } \\
\text { Dampak Perekonomian, } \\
\text { UMKM }\end{array}$ & $\begin{array}{l}\text { ABSTRAK: Pandemi Covid-19 masih menjadi momok hingga saat ini. Selain } \\
\text { memberikan dampak pada Kesehatan, pandemi ini juga sangat memberikan dampak } \\
\text { pada perekonomian secara Nasional. UMKM yang dianggap mampu bertahan pada } \\
\text { Krisis Moneter } 1998 \text { dan Krisis Global 2008, kini seperti tidak berdaya menghadapi } \\
\text { pandemi covid-19. } \\
\text { Dampak Pandemi Covid-19 tidak hanya dirasakan UMKM yang berada di Kota besar } \\
\text { saja, UMKM yang berada jauh dari Kota juga merasakan dampak yang sama, } \\
\text { sebagaimana yang dirasakan oleh para Pengusaha kerupuk kulit di Desa Apitaik } \\
\text { Kabupaten Lombok Timur. } \\
\text { Hasil wawancara dengan beberapa informan menunjukkan, permintaan kerupuk kulit } \\
\text { selama pandemi naik, tapi produsen tidak berani menaikkan harga karena khawatir } \\
\text { produknya tidak terserap di pasar. Selain itu, banyaknya penjual yang menjual dengan } \\
\text { harga murah membuat para pengusaha kerupuk kulit masih menggunakan harga } \\
\text { sebelum pandemi. } \\
\text { Pengusaha kerupuk kulit memilih memangkas margin mereka karena kenaikan harga } \\
\text { bahan baku dan tarif ekspedisi daripada menaikkan harga jual. Akibatnya, tidak } \\
\text { sedikit pengusaha kerupuk kulit yang harus menurunkan upah pegawainya atau } \\
\text { bahkan merumahkan pegawainya. }\end{array}$ \\
\hline
\end{tabular}

Corresponding Author :

Alamat : Program Studi Ekonomi Pembangunan, Fakultas Ekonomi dan Bisnis, Universitas Mataram, Jln. Majapahit No. 62 Mataram.

e-mail: ab.singandaru@unram.ac.id 


\section{PENDAHULUAN}

\section{Latar Belakang}

Penyebaran virus Covid-19 masih menjadi momok hingga saat ini, bahkan virus tersebut sudah bermutasi menjadi beberapa macam varian. Sejak pertama kali dideklarasikan sebagai pandemi global oleh WHO pada tanggal 9 Maret 2020 hingga 15 September 2021, berdasarkan rilis data website covid.19.go.id, jumlah pasien yang terkonfirmasi hingga saat ini telah mencapai angka 4.174.216, dengan jumlah korban meninggal dunia sebanyak 139.415 jiwa, 3.942.473 jiwa sudah sembuh, dan yang masih aktif atau positif sebanyak 92.328 jiwa. Angka ini tersebar di seluruh wilayah Indonesia dengan persentase terbesar untuk wilayah DKI Jakarta sebesar 20,5\%, dan terendah 0,3\% untuk wilayah Maluku, Maluku Utara, Sulawesi Barat, dan Gorontalo.

Sejak kasus pertama pasien covid-19 dilaporkan pada bulan maret 2020, Pemerintah telah memberlakukan berbagai kebijakan yang terkait dengan penanganan Kesehatan sekaligus menjaga stabilitas perekonomian. Namun, Selain data terkait Kesehatan di atas, data yang dirangkum oleh Kementerian Pariwisata dan Ekonomi Kreatif (Kemenparekraf) dalam Buku Tren Pariwisata 2021 menunjukkan, selama tahun 2020, terjadi penurunan jumlah wisatawan yang berkunjung ke Indonesia hingga 75\% dibandingkan tahun 2019. Dampak pandemi COVID-19 pada sektor pariwisata Indonesia juga terlihat dari pengurangan jam kerja. Sekitar 12,91 juta orang di sektor pariwisata mengalami pengurangan jam kerja, dan 939 ribu orang di sektor pariwisata sementara tidak bekerja.

Data survei lain terkait perekonomian nasional juga menunjukkan, bahwa selama pandemi, 94,69\% usaha mengalami penurunan penjualan. Berdasarkan skala usaha, penurunan penjualan lebih dari $75 \%$ dialami oleh $49,01 \%$ usaha ultramikro, 43,3\% usaha mikro, $40 \%$ usaha kecil, dan 45,83\% usaha menengah. Berdasarkan lama usaha, penurunan penjualan lebih dari $75 \%$ dialami oleh $23,27 \%$ usaha berusia 0-5 tahun, $10,9 \%$ usaha berusia 6-10 tahun dan $8,84 \%$ usaha yang telah berjalan lebih dari 10 tahun. Berdasarkan metode penjualan, penurunan penjualan lebih dari $75 \%$ dialami oleh $47,44 \%$ usaha penjualan offline/fisik, 40,17\% usaha penjualan online, dan $39,41 \%$ usaha dengan metode penjualan offline sekaligus online (LIPI, 2020).

\section{Rumusan Masalah}

Berdasarkan latar belakang di atas, peneliti ingin mengetahui Bagaimana dampak pandemi covid-19 pada pengusaha kerupuk kulit di Desa Apitaik Kabupaten Lombok Timur yang termasuk sebagai salah satu UMKM.

\section{Tujuan Penelitian}

Mengetahui bagaimana dampak pandemi covid-19 pada pengusaha kerupuk kulit di Desa Apitaik Kabupaten Lombok Timur.

\section{KAJIAN PUSTAKA}

\section{Teori Permintaan}

Teori permintaan menyatakan bahwa harga dan tingkat permintaan suatu barang memiliki hubungan yang bersifat 
negatif. Ketika harga suatu barang naik, maka permintaan terhadap barang tersebut akan menurun, ceteris paribus dan demikian pula sebaliknya. Namun, harga bukanlah satu-satunya faktor penentu naik-turunnya permintaan terhadap suatu barang. Faktor-faktor lain penentu permintaan terhadap suatu barang selain harga barang itu sendiri diantaranya adalah:

1. Harga barang lain, baik yang bersifat substitusi maupun komplementer terhadap barang tersebut.

2. Tingkat pendapatan.

3. Selera atau kebiasaan.

4. Jumlah penduduk

5. Perkiraan harga di masa yang akan datang

6. Distribusi pendapatan, dan

7. Promosi

\section{Teori Penawaran}

Teori penawaran menyatakan bahwa harga dan tingkat penawaran suatu barang memiliki hubungan yang bersifat positif. Ketika harga suatu barang naik, maka penawaran terhadap barang tersebut akan mengalami kenaikan, ceteris paribus, dan demikian pula sebaliknya. Sebagaimana teori permintaan, faktor harga bukanlah satu-satunya faktor yang mempengaruhi tingkat penawaran yang dilakukan oleh produsen. Ada beberapa faktor selain harga barang itu sendiri yang mempengaruhi tingkat penawaran, diantaranya adalah:

1. Harga barang lain yang terkait, baik yang bersifat substitusi dan komplementer

2. Harga faktor produksi

3. Biaya produksi

4. Tekhnologi

5. Jumlah penjual, dan

\section{Kebijakan pemerintah}

\section{UMKM}

Berdasarkan Undang-Undang (UU) No. 20 Tahun 2008, Usaha Mikro adalah usaha produktif milik orang perorangan dan/atau badan usaha perorangan yang memenuhi kriteria Usaha Mikro. Adapun Kriteria Usaha Mikro adalah, a) memiliki kekayaan bersih paling banyak Rp50.000.000,00 (lima puluh juta rupiah) tidak termasuk tanah dan bangunan tempat usaha; atau b) memiliki hasil penjualan tahunan paling banyak Rp300.000.000,00 (tiga ratus juta rupiah).

Sedangkan Usaha Kecil adalah usaha ekonomi produktif yang berdiri sendiri, yang dilakukan oleh orang perorangan atau badan usaha yang bukan merupakan anak perusahaan atau bukan cabang perusahaan yang dimiliki, dikuasai, atau menjadi bagian baik langsung maupun tidak langsung dari Usaha Menengah atau Usaha Besar yang memenuhi kriteria Usaha Kecil. Kriteria Usaha Kecil adalah, a) memiliki kekayaan bersih lebih dari Rp50.000.000,00 (lima puluh juta rupiah) sampai dengan paling banyak Rp500.000.000,00 (lima ratus juta rupiah) tidak termasuk tanah dan bangunan tempat usaha; atau b) memiliki hasil penjualan tahunan lebih dari Rp300.000.000,00 (tiga ratus juta rupiah) sampai dengan paling banyak Rp2.500.000.000,00 (dua milyar lima ratus juta rupiah).

Usaha Menengah sendiri sebagaimana yang diatur dalam UU No. 20 Tahun 2008 adalah usaha ekonomi produktif yang berdiri sendiri, yang dilakukan oleh orang perorangan atau badan usaha yang bukan merupakan anak perusahaan atau cabang perusahaan yang dimiliki, dikuasai, atau 
menjadi bagian baik langsung maupun tidak langsung dengan Usaha Kecil atau Usaha Besar yang memenuhi kriteria Usaha Menengah. Adapun kriteria Usaha Menengah adalah, a) memiliki kekayaan bersih lebih dari Rp500.000.000,00 (lima ratus juta rupiah) sampai dengan paling banyak Rp10.000.000.000,00 (sepuluh milyar rupiah) tidak termasuk tanah dan bangunan tempat usaha; atau b) memiliki hasil penjualan tahunan lebih dari Rp2.500.000.000,00 (dua milyar lima ratus juta rupiah) sampai dengan paling banyak Rp50.000.000.000,00 (lima puluh milyar rupiah).

Berdasarkan data yang dirilis oleh Kementerian Koperasi dan Usaha Kecil dan Menengah, jumlah UMKM pada tahun 2019 (Angka sangat sementara) di Indonesia sebanyak 65.465.497, mengalami peningkatan sebanyak 1.271 .440 atau $1,98 \%$ jika dibandingkan dengan jumlah UMKM pada tahun 2018. Dengan jumlah yang mencapai 65 juta lebih tersebut, UMKM mampu menyerap Tenaga Kerja sebanyak 119.562.843 orang, dan berkontribusi terhadap PDB atas dasar harga konstan sebesar 7.034,1 triliun Rupiah, mengalami peningkatan sebesar 22,95\% jika dibandingkan dengan tahun 2018 sebesar 5.721,1 triliun Rupiah.

\section{Corona Virus Deseases (COVID-19)}

Situs resmi WHO mendefinisikan Corona virus adalah virus yang mampu menyerang saluran pernafasan manusia dan hewan. Untuk manusia, Corona virus mampu menyebabkan penyakit yang mematikan seperti MERS, SARS, dan yang terbaru Covid-19. Saat ini Covid-19 telah menjadi pandemi global yang telah memakan jutaan korban jiwa di seluruh negara.
Berdasarkan rilis data dari situs resmi pemerintah Indonesia, sejak Maret 202015 September 2021, jumlah pasien yang terkonfirmasi saat ini telah mencapai angka 4.174.216, dengan jumlah korban meninggal dunia sebanyak 139.415 jiwa, 3.942.473 jiwa sudah sembuh, dan yang masih aktif atau positif sebanyak 92.328 jiwa. Angka ini tersebar di seluruh wilayah Indonesia dengan persentase terbesar untuk wilayah DKI Jakarta sebesar 20,5\%, dan terendah 0,3\% untuk wilayah Maluku, Maluku Utara, Sulawesi Barat, dan Gorontalo.

Dalam rangka penanganan Covid-19, pemerintah telah mengeluarkan kebijakan tentang Pembatasan Sosial Berskala Besar yang merujuk pada Undang-undang Nomor 6 Tahun 2018 tentang Kekarantinaan Kesehatan. Peraturan pelaksanaannya yaitu Peraturan Pemerintah Nomor 21 Tahun 2020 tentang Pembatasan Sosial Berskala Besar, serta Keputusan Presiden tentang Kedaruratan Kesehatan. Untuk menganggulangi dampak Covid-19 dari segi ekonomi dan sosial pemerintah mengambil beberapa kebijakan-kebijakan, yang diantaranya adalah: Peraturan Menteri Keuangan Republik Indonesia Nomor 23/Pmk.03/2020 tentang Insentif Pajak Untuk Wajib Pajak Terdampak Wabah Virus Corona; Peraturan Otoritas Jasa Keuangan Republik Indonesia Nomor 11 /Pojk.03/2020 tentang Stimulus Perekonomian Nasional Sebagai Kebijakan Countercyclical Dampak Penyebaran Corona Virus Disease 2019; dan Instruksi Presiden Republik Indonesia Nomor 4 Tahun 2020 tentang Refocussing Kegiatan, Realokasi Anggaran, Serta Pengadaan Barang Dan Jasa Dalam Rangka Percepatan 
Penanganan Corona Virus Disease 2019 (Covid-19). Selain itu pemerintah juga mengambil kebijakan seperti keringanan biaya listrik, keringanan kredit, dan menggelontorkan anggaran Rp. 405,1 triliun untuk memenuhi kebutuhan ditengah wabah Covid-19 melalui Anggaran Pendapatan Belanja Negara 2020 sebagai wujud bantuan kepada masyarakat (Wiryawan, 2020)

\section{Penelitian Terdahulu}

Penelitian yang terkait dengan dampak Pandemi Covid-19 terhadap UMKM di Indonesia sudah banyak dilakukan, diantaranya adalah penelitian yang dilakukan oleh Evi Suryani terhadap pedagang klepon di Driyorejo, Gresik. Penelitian yang menggunakan metode kualitatif ini menyimpulkan bahwa terjadi penurunan omzet hingga $60 \%$ akibat pandemi covid-19.

Penelitian yang dilakukan oleh Rizki Nor Azimah di tiga pasar di daerah Klaten dan Wonogiri juga menunjukkan terjadinya penurunan omzet akibat pandemi covid-19 hingga $50 \%$ yang dirasakan oleh para pedagang di tiga pasar di daerah Klaten dan Wonogiri tersebut.

Hasil kajian dampak pandemi covid-19 terhadap UMKM di Kabupaten Buleleng yang dilakukan oleh Badan Penelitian, Pengembangan, dan Inovasi Daerah Kabupaten Buleleng dengan Lembaga Penelitian dan Pengabdian kepada masyarakat Universitas Pendidikan Ganesha Singaraja menunjukkan bahwa dampak yang ditimbulkan oleh pandemi Covid-19 meliputi lima aspek, yaitu aspek penjualan, aspek laba usaha, aspek permodalan, aspek jumlah karyawan, dan aspek kemampuan pembayaran angsuran Bank. Untuk aspek penjualan dan laba usaha, UMKM di Kabupaten Buleleng mengalami penurunan omzet dan laba usaha hingga sebesar 61\%. Sedangkan untuk aspek permodalan, jumlah UMKM yang mengalami permasalah modal meningkat menjadi $71,4 \%$. Untuk aspek karyawan, pelaku UMKM melakukan pengurangan jumlah karyawan sebesar $22 \%$, dan untuk aspek terakhir, hampir semua UMKM mengalami kendala dalam melaksanakan kewajibannya terhadap perbankan.

Dari ketiga penelitian tersebut, menyimpulkan bahwa pandemi Covid-19 sangat berdampak pada permintaan yang mempengaruhi omzet dan laba para pelaku UMKM. Selain itu, para peneliti juga menyarankan agar para pelaku UMKM melakukan 'Shifting' dalam penjualan mereka secara on-line dengan memaksimalkan media sosial mereka sehingga bisa meningkatkan penjualan.

\section{METODE PENELITIAN}

Penelitian ini dilakukan di Desa Apitaik Kecamatan Pringgabaya Kabupaten Lombok Timur. Lokasi ini dipilih karena Desa Apitaik merupakan salah satu sentra usaha kerupuk kulit yang lokasinya sangat jauh dari pusat kota, jika dibandingkan dengan sentra usaha kerupuk kulit lainnya. Selain itu, penambahan jumlah pengusaha kerupuk kulit di desa ini dalam kurun waktu satu tahun, menjadikan desa ini menarik untuk diteliti.

Penelitian ini merupakan penelitian deskriptif kualitatif. Data yang digunakan adalah data primer yang diperoleh melalui hasil wawancara dari beberapa informan, yaitu pengusaha kerupuk kulit yang ada di Desa Apitaik. Adapun Analisa data yang 
digunakan adalah model Analisa interaktif, yang terdiri dari mereduksi data atau informasi yang diperoleh melalui hasil wawancara dengan para informan, untuk kemudian disajikan dalam bentuk uraian singkat agar informasi yang didapatkan lebih mudah dipahami, dan menarik kesimpulan untuk menjawab perumusan masalah yang ada.

\section{HASIL DAN PEMBAHASAN}

Berdasarkan hasil wawancara dengan beberapa informan, Harga jual kerupuk kulit selama masa pandemi (Maret 2020Juni 2021) masih sama dengan sebelum pandemi, yaitu diantara Rp 65.000-Rp 90.000, tergantung kualitas kerupuk yang dijual. Penggunaan harga tersebut dilakukan oleh para pengusaha kerupuk kulit karena khawatir produk mereka tidak terserap di pasar, mengingat keadaan ekonomi saat ini sangat tidak menentu. Dengan harga tersebut, permintaan kerupuk kulit mengalami kenaikan ratarata sebesar $8 \%$ di rentang waktu yang sama.

Kenaikan tersebut diakibatkan oleh faktor kebiasaan atau selera masyarakat yang ketika makan harus ada kerupuk sebagai pendamping. Kenaikan ini juga disebabkan oleh kebijakan Pembelajaran Jarak Jauh (PJJ) di Kota Mataram untuk semua tingkat Pendidikan, yang mengakibatkan para pelajar dan mahasiswa yang biasanya tinggal di Kota Mataram selama masa pembelajaran, harus tinggal di daerah asal masing-masing. Bertambahnya anggota keluarga membuat pembelian kerupuk harus bertambah karena adanya faktor kebiasaan yang sudah dijelaskan di atas.
Untuk jumlah produksi, di rentang waktu yang sama, para informan memproduksi rata-rata sebesar $98 \mathrm{~kg}$ per harinya yang habis dijual rata-rata paling lama 3 hari. Jumlah ini masih sama seperti jumlah produksi mereka biasanya ketika sebelum pandemi. Kenaikan permintaan sebesar $8 \%$ tersebut tidak membuat para pengusaha kerupuk kulit serta merta menaikkan jumlah produksinya. Hal ini dilakukan karena naiknya harga bahan baku dan tarif ekspedisi yang rata-ratanya sebesar $25 \%$ jika dibandingkan dengan sebelum pandemi. Selain itu, banyaknya penjual baru ketika pandemi yang menjual kerupuk kulit kualitas rendah dengan harga murah menjadikan mereka lebih memilih untuk menetapkan harga seperti sebelum pandemi. "Sekarang lagi susah, kalau orang mau makan kerupuk, mereka gak pikir ini kualitas satu apa tidak, yang penting kerupuk", ucap salah satu informan. Kekhawatiran produk mereka tidak akan terserap di pasar menjadi alasan utama mereka untuk tidak menaikkan harga jual, dan tidak menambah jumlah produksi, walaupun permintaan naik dan tarif ekspedisi serta harga bahan baku mengalami kenaikan.

Keadaan ini menyebabkan margin keuntungan yang diperoleh oleh para informan mengalami penurunan rata-rata sebesar $38 \%$. Penurunan margin tersebut diakibatkan oleh kenaikan biaya produksi yang terdiri dari kenaikan harga bahan baku, dan kenaikan tarif ekspedisi yang rata-ratanya sebesar 25\% dibandingkan sebelum pandemi. Penurunan margin tersebut mengakibatkan beberapa informan merumahkan beberapa karyawan mereka. Tugas dari karyawan yang dirumahkan diambil alih oleh 
informan tersebut. Bahkan ada beberapa informan yang menurunkan upah karyawannya agar tidak perlu merumahkan karyawannya. Beberapa informan juga ada yang melakukan penambahan modal usaha untuk mendapatkan sumber bahan baku kulit sapi yang lebih murah dari luar pulau Lombok. Namun, Pemberlakuan protokol Kesehatan berupa kewajiban bagi para pelaku perjalanan untuk melakukan Swab Antigen dan PCR, menjadikan biaya untuk mendapatkan sumber bahan baku yang lebih murah menjadi bertambah.

Kondisi di atas menyebabkan beberapa informan mulai mencoba untuk memperluas pangsa pasar dan ruang lingkup usahanya. Jika selama ini mereka hanya menjual produk olahan jadi berupa kerupuk kulit, kini mereka mulai mencoba untuk menjual olahan setengah jadi seperti kulit siap goreng, dan pencok/krecek. Untuk harga kulit siap goreng, harga yang diberikan lebih tinggi dibandingkan yang sudah digoreng menjadi kerupuk, yaitu diantara Rp 100.000-Rp 120.000/kg. Untuk produk setengah jadi lainnya seperti bahan kulit untuk produk pencok/krecek dihargai lebih murah, yaitu diantara $\mathrm{Rp} 60.000-\mathrm{Rp}$ $75.000 / \mathrm{kg}$.

Selain itu, para informan juga mulai mencoba menerapkan sistem re-seller dan penjualan secara on-line untuk produk jadi mereka. Pasaran yang ditarget adalah rumah tangga, sehingga kerupuk kulit yang dijual adalah kemasan di bawah $1 \mathrm{~kg}$. Para informan berharap, cara ini akan meningkatkan jumlah margin penjualan mereka karena harga jual kerupuk kemasan $1 / 2$ dan $1 / 4 \mathrm{~kg}$ tentu bisa lebih tinggi dibandingkan kemasan $1 \mathrm{~kg}$.
Namun, dengan keadaan sebagaimana yang telah dijelaskan di atas, jumlah para pengusaha dan penjual kerupuk kulit di Desa Apitaik justru mengalami kenaikan selama rentang waktu maret 2020-Juni 2021. Hal ini terjadi karena para karyawan yang dirumahkan justru ikut terjun dalam usaha kerupuk kulit. Dengan modal yang ada, mereka membeli bahan baku dari pengusaha kerupuk kulit besar lainnya yang ada di sekitar mereka, dan kemudian mengolahnya untuk kemudian dijual kembali. "Ya daripada kita gak makan kan, kita Taunya cuma ini aja, kita beli secukupnya, goreng, trus jual lagi. Untuk kualitasnya kita campur biar gak terlalu besar biayanya, dan kita bisa jual lumayan murah", ucap mereka.

\section{KESIMPULAN DAN SARAN}

Kenaikan permintaan kerupuk kulit selama masa pandemi tidak mampu memberikan keuntungan lebih bagi para pengusaha kerupuk kulit di Desa Apitaik Kabupaten Lombok Timur. Hal ini diakibatkan oleh kenaikan biaya produksi seperti kenaikan harga bahan baku dan tarif ekspedisi, sedangkan menaikkan harga jual bukan opsi yang tepat bagi para pengusaha tersebut karena akan menyebabkan konsumen tidak mau membeli produk mereka.

Keadaan tersebut memaksa para pengusaha kulit untuk memotong margin penjualan mereka, yang akhirnya berdampak pada kebijakan yang diambil oleh para pengusaha kerupuk kulit tersebut. Agar tetap dapat bertahan, para pengusaha mengambil Langkah-langkah seperti merumahkan karyawan, memotong upah karyawan, mencari 
sumber bahan baku yang lebih murah dengan menyuntikkan modal usaha tambahan untuk jangka panjang, menjual produk setengah jadi, langsung menyasar pasar rumah tangga dengan menjual produk dalam kemasan di bawah $1 \mathrm{~kg}$ dengan menggunakan jasa re-seller dan menggunakan media online.

Stakeholder terkait diharapkan memberikan bantuan bagi para pengusaha kerupuk kulit tersebut yang terhitung masih UMKM agar dapat tetap bertahan, karena bagaimanapun mereka bisa menyerap tenaga kerja yang tidak sedikit. Bantuan yang diberikan bisa berupa bantuan alat produksi, pelatihan dan pendampingan untuk pengemasan yang higienis serta bagaimana memperoleh izin P-IRT/BPOM, sehingga produk kemasan para pengusaha kerupuk kulit tersebut bisa masuk ke setiap minimarket dan supermarket local, sehingga pasaar yang dijangkau bisa lebih luas lagi.

\section{DAFTAR PUSTAKA}

https://covid19.go.id/peta-sebaran-covid19, diakses pada tanggal 15 September 2021 https://kemenparekraf.go.id/ragam-pariwisata/Tren-Pariwisata-Indonesia-di-Tengah-

Pandemi, diakses pada tanggal 15 September 2021

http://lipi.go.id/berita/survei-kinerja-umkm-di-masa-pandemi-covid19/22071, diakses pada tanggal 9 September 2021

https://www.kemenkopukm.go.id/data-umkm, diakses pada tanggal 9 September 2021

Rahardja, Pratama, Manurung, Mandala. Pengantar Ilmu Ekonomi, Mikroekonomi, dan Makroekonomi. Jakarta: LPFE UI. 2008

Sukirno, Sadono. Mikroekonomi, Teori Pengantar Edisi Ketiga. Depok: Rajawali Pers. 2019.

Undang-Undang Republik Indonesia Nomor 20 Tahun 2008 Tentang Usaha Mikro, Kecil, dan Menengah

Wiryawan, I Wayan. Kebijakan Pemerintah dalam Penanganan Pandemi Virus Corona Desease 2019 (Covid-19) di Indonesia. Prosiding Seminar Nasional Webinar Nasional Universitas Mahasaraswati Denpasar, Percepatan Penanganan COVID-19 Berbasis Adat di Indonesia. Denpasar, 26 JUni 2020. Universitas Mahasaraswati.

Suryani, E. (2020). Analisis Dampak Covid-19 Terhadap UMKM (studi kasus home industri klepon di Kota Baru Driyorejo). Jurnal Inovasi Penelitian, 1(8), 1591-1596. https://doi.org/10.47492/jip.v1i8.272

Nor Azimah Rizki, dkk. Analisis Dampak Covid-19 Terhadap Sosial Ekonomi Pedagang di Pasar Klaten dan Wonogiri. Jurnal Ilmu Kesejahteraan Sosial, Volume 9 No. 1 Juni 2020, 59-68. DOI:10.15408/empati.v9i1.16485

Kajian Dampak Pandemi Covid-19 terhadap UMKM di Kabupaten Buleleng. Badan Penelitian, Pengembangan, dan Inovasi Daerah Kabupaten Buleleng dengan Lembaga Penelitian dan Pengabdian Kepada Masyarakat Universitas Pendidikan Ganesha Singaraja. 2020. 